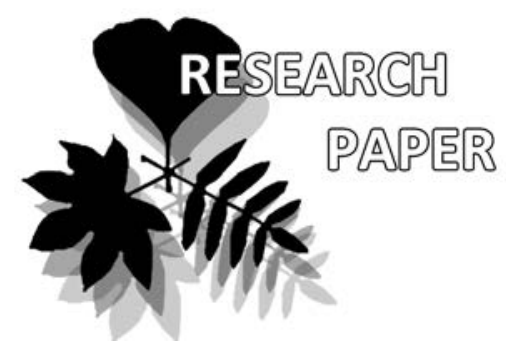

\title{
Sex dimorphism in shoot morphology of Antennaria dioica (L.) Gaertner (Compositae)
}

\author{
Ksenia V. Dudova
}

Ksenia V. Dudova

e-mail: k.v.dudova@yandex.ru

Department of Geobotany, Faculty of Biology, Lomonosov Moscow State University, Moscow, Russia

Manuscript received: 22.01.2016

Review completed: 10.01.2019

Accepted for publication: 28.01.2019

Published online: 31.01.2019

\begin{abstract}
A B S T R A C T
Determination the sex of the plant shoots without using features of a separate capitulum is important in population-based studies. I tested hypothesis that Antennaria dioica has statistically significant differences in morphological traits between female and male shoots. Eight morphological features and 1907 shoots from the three geographically separated regions were studied. Reliable difference was found in height of generative shoots, rosette diameter and number of cauline leaves. However, the traits studied had significant overlap within individual populations and did not demonstrate significant differencces within a region. Therefore, none of the traits presented can be used to determine the sex of an individual.
\end{abstract}

K e y w o r d s : dioecy, sex dimorphism, Antennaria dioica, morphological traits

\section{P E 3 Ю M E}

Аудова К.В. Проявления полового диморфизма в морфологии побегов Antennaria dioica (L.) Gaertner (Compositae). В популяционных исследованиях Авудомных растений актуально определение пола побегов без использования признаков генеративной сферы. А^я Antennaria dioica проверена гипотеза о том, что по морфологическим признакам женские и мужские побеги этого вида значимо разАичаются. Аیя исследования полового Аиморфизма выбрано восемь признаков. Изучено 1907 побегов из трех географически удаленных регионов. Найдены достоверные различия межАу полами по признакам: высота генеративного прироста, Аиаметр прикорневой розетки и число Аистьев на генеративном приросте. При этом, по всем исследованным признакам выяв еено значительное их перекрывание в рамках отАельных популяций и отсутствие значимых разАичий в рамках отАельных регионов. Поэтому ни один из представ енных признаков не может быть использован Аля определения пола отАельной особи.

КАючевые слова: двудомность, половой диморфизм, Antennaria dioica, морфологические признаки
Dioecious plants possess primary and secondary sexual traits. Primary sexual traits relate to gynoecium or androecium in a flower. Individuals of opposite sexes may differ in morphological (Lloyd \& Myall 1975, Thomas \& LaFrankie 1993, Webb at al. 1999), biochemical (Manoilov 1924), physiological (Cipollini \& Whigham 1994, Dawson \& Geber 1999), ecological (Meagher 1984, Dawson \& Geber 1999, Barret 2002) and other traits. Secondary traits may include differences between the sexes in either flower morphology or biology (Godin 2007).

It is supposed that dimorphism of secondary sexual traits is associated with different strategies of males and females, especially in aspects related to growth and reproductive costs (Delph et al. 2003, Barret 2012). For example, female plants require more resources to produce seeds (Varga \& Kytoeviita 2008). Differences in secondary sexual characters are directly connected with differences in sex chromosomes in some species (Lloyd \& Webb 1977, Delph 2003, Zluvova et al. 2006). For instance, the flower size of both male and female individuals of Silene latifolia Poir. (Caryophyllaceae) is regulated by some changes in DNA like accumulation or deletion with repetitive sequences (Meag- ner \& Costich 1994). For species without sex chromosomes, the key role in the regulation of secondary sexual characters manifestation in individuals is played by the environmental factors (Rottenberg 1998). Modern molecular methods of determining an individual's sex can also be used, for example, using the specific genetic markers for both sexes (Parasnis et al. 1999, Shibu et al. 2000, Stehlik \& Blattner 2004). Effectiveness of such methods as RAPD (random amplified polymorphic DNA) and BSA (bulked segregant analysis) was demonstrated for a number of species (Persson \& Nybom, 1998). SCAR-markers were successfully used for Cannabis sativa L. (Cannabaceae) (Mandolino et al. 1999). These methods allow determining the sex of individual plants accurately, but budget-consuming for searching species-specific markers.

Other manifestations of the sex dimorphism in plants like biochemistry are less studied. Manoilov (1924) offered to distinguish sexes "by a chemical reaction" tested on several dioecious species. Interaction between plant individuals of different sexes and mycorrhizae can also indicate sex dimorphism, as it was shown for Distichlis stricta (Torr.) Rydb. (Gramineae). Mycorrhiza biomass in the roots of female 
individuals of the species is $\times 1.62-2.58$ higher than in male ones (Epley et al. 2009). The same pattern is observed for A. dioica (Varga \& Kytoeviita 2008). Besides, sex dimorphism in plants may be manifested functionally. Female and male flowers of Rubus chamaemorus L. (Rosaceae) have similar morphology, but male ones tend to excrete copious amounts of nectar while excretion in female flowers is extremely low (Korpelainen 1994). Male individuals of $A$. dioica are able to produce more ramets than female ones but only under specific ecological conditions (Varga 2010).

Dimorphism of secondary sexual traits manifested through morphology of plant reproductive structures is well studied. For example, corolla tube diameter differs between male and female individuals in Melandrium album (Mill.) Garcke (Caryophyllaceae) and Chassalia corallioides (Cordem.) Verdc. (Rubiaceae) (Gulenkova \& Pyatunina 1996, Pailler at al. 1998). Male flowers of Ecballium elaterium (L.) A. Rich. (Cucurbitaceae) are larger than female ones (Costish \& Meagner 2001).

Sex dimorphism occurs more rarely in vegetative parts of shoots (Midgley 2010). For example, different sexes of Cannabis sativa plants can be distinguished by shoot height and sometimes by number of metamers (Miller 1970). Generally, traits that allow to distinguish sexes in plants are quantitative and applicable only after a number of measurements and subsequent statistical processing (Miller 1970, Pailler at al. 1998, Costish \& Meagner 2001).

Distinguishing sexes in plants observed during nonreproductive life history stage may be used in practice. In population studies of dioecious species it is often required to know the correct sexes of plant individuals (Alliende \& Harper 1989, Gibson 1994, Hultine et al. 2007). Population studies and monitoring of endangered species have recently been especially relevant; to evaluate the population viability, the sex of every individual should be taken into account (Osunkoya 1999). Population structure studies, calculating male:female ratio, separate mapping of individual plants of different sexes also require distinguishing plant sexes. In most studies, however, it is impossible, so researchers often summarize juvenile, virginile and senile life history stages for all plant individuals (Meagner 1984).

Sex of blooming individuals can be identified by primary sexual traits together with a complex of secondary ones evident from flowering shoots. Otherwise, it is necessary to know secondary sexual traits for target species.

Antennaria dioica (Compositae) is a boreal Eurasian dioecious long-rhizome perennial clonal plant (Borisova 1959, Engelskjen \& Skifte 1995). For some North American Antennaria species the differences in male and female plant morphology was described earlier (Chmielewski et al. 1990). Such studies were not conducted for $A$. dioica. Phenomenon of sex dimorphism in this species was described, but considering either capitula morphology or only flowers (Borisova 1959). Traits usable for distinguishing sexes of individual plants without reproductive structures are not mentioned in the cited studies.

Our main hypothesis stated that $A$. dioica has statistically significant differences in morphological traits between female and male shoots.

\section{MATERIAL AND METHODS}

Aboveground monocarpic shoots of Antennaria dioica were collected in June and July 2012 in three regions:

1) Bulgaria (05.07.2012-07.07.2012; $\left.42.15^{\circ} \mathrm{N}, 23.77^{\circ} \mathrm{E}\right)$, in communities of alpine heaths (class Juncetea trifidi Hadać in Klika et Hadač 1944).

2) Tver region, Russia (02.06.2012-04.06.2012; $57.63^{\circ} \mathrm{N}$, $35.66^{\circ} \mathrm{E}$ ), on dry meadows (Koelerio-Corynephoretea Klika in Klika et Novák 1941) and in dry pine forests with Cladonia (Vaccinio-Piceetea Br.-Bl. in Br.-Bl. et al. 1939).

3) Murmansk region, Russia (18.07.2012-25.07.2012; $66.76^{\circ} \mathrm{N}, 33.75^{\circ} \mathrm{E}$ ), in coastal communities (Loiseleurio procumbentis-Vaccinietea Eggler ex Schubert 1960) and in pine forests (Vaccinio-Piceetea Br.-Bl. in Br.-Bl. et al. 1939).

To study sex dimorphism in shoots of $A$. dioica, specific traits easily distinguished during field observations were chosen. Monocarpic shoot of $A$. dioica consists of a rhizome with plagiotropic growth (a rhizome is absent if a rosette was originated from seeds), a vegetative part with ortotropic growth and shortened internodes, and, if present, a reproductive part with a terminal inflorescence.

For every flowering shoot the following traits were considered:

1) sex (male, female; based on the flower morphology);

2) height of its ortotropic part;

3) diameter of a rosette formed by vegetative and generative parts of shoots;

4) number of cauline leaves;

5) number of capitula in the inflorescence;

6) shape of leaf apex including "pointed", "slightly pointed" and "round"; fully developed leaves in the middle of vegetative rosettes was studied (Fig. 1);

7) hair density on the adaxial surface of leaves with three categories (1) almost naked leaves with solitary light hairs; (2) sparsely hairy leaves with grayish lamina; (3) densely hairy leaves, silver-shaded in the sunlight; hair density was assessed visually;

8) general color of a capitula; three capitula colors were observed: (1) white, (2) light-pink, (3) pink, including darkpink variants.

In total, 1908 shoots were measured, where 968 were male and 940 female ones.

The data were analyzed in R-Studio V. 1.1. 456. For the basic data preparing I used 'dplyr' (Wickham et al. 2018) and 'base' (R Core Team 2018) packages. Statistics were calculated by 'stats' package (R Core Team 2018). Graphs was builded with the 'ggplot2' package (Wickham et al. 2018). Mean trait values were calculated for quantitative traits (shoot height and rosette diameter). To test normality, ShapiroWilk test was used. Normally distributed measured traits between male and female shoots were compared by Welch Two Sample t-test. In other cases, Kruskal-Wallis rank-sum test or Wilcoxon Rank Sum and Signed Rank Tests were used. Variations of samples were compared with $\mathrm{F}$ test to compare two variances. Spearman's rank correlation method was used for correlation analysis.

\section{RES ULTS}

The sample by plant height has normal distribution $(\mathrm{W}=0.94$, p-value $<2.2 \mathrm{e}-16)$. The shoot height varies from 


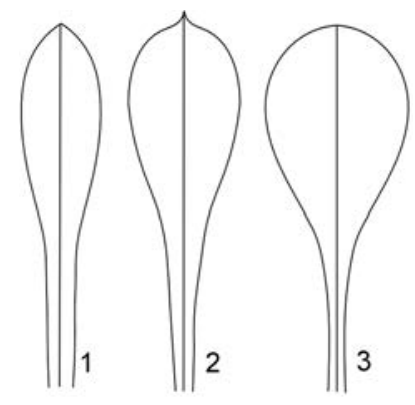

Figure 1 Shape of leaf apex: 1 - "slightly pointed", 2 "pointed", 3 - "round"
$1.2 \mathrm{~cm}$ to $52 \mathrm{~cm}$, with the coefficient of variation $35 \%$. The minimum values of the trait are recorded in alpine heath communities (the Rila mountains, Bulgaria) and in the coastal communities (Murmansk region). The highest values were recorded in pine forests and meadows. The average height in the sample is $15 \pm 0.1 \mathrm{~cm}(12 \pm$ $0.1 \mathrm{~cm}$ for males, $19 \pm$ $0.2 \mathrm{~cm}$ for females).

The coefficients of variation for the height is $37 \%$ for female shoots and $15.5 \%$ for male shoots. At the same time, height variation for male and female shoots is not statistically different $(\mathrm{F}=2.4$, $\mathrm{p}$-value $<2.2 \mathrm{e}-16)$. The height of male and female shoots significantly differ statistically (Table 1), but at the level of specific populations, the height values for both sexes overlap to a great extent (Fig. 2A). It makes this trait useless in distinguishing individual shoots sex. In the populations of Tver region, the sexes do not differ by this trait (Table 1, Fig. 3C).

The number of leaves on the generative shoot ranges from 1 to 15 , the mode of sample is 5 . At the same time, the number of leaves does not correlate linearly with the plant height $(r<0.5)$ either in generalized sample or in in specific sexes. A small number of leaves (up to 4) was recorded for the plants up to $25 \mathrm{~cm}$ high; the largest number of leaves is observed for $17-21 \mathrm{~cm}$ shoots; for most trait values, a significant variation in height $(4-52 \mathrm{~cm})$ is typical (Fig. 4A).

Female individuals, on average, have six leaves, while the male ones have four (Table 1). Within the same population, both males and females could have the same number of leaves. Besides, for the populations of the Moscow and
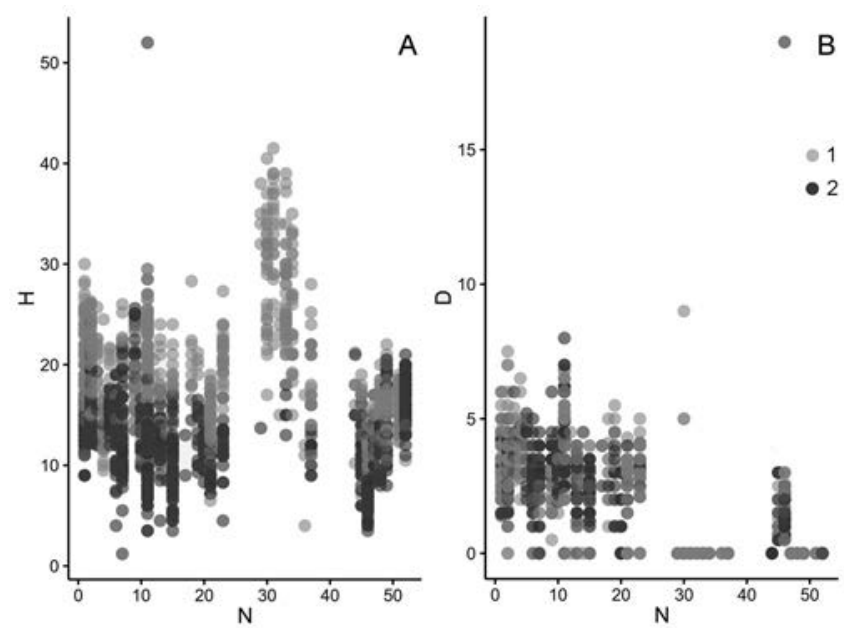

Figure 2 Scatterplots of: A -values of the generative shoot heights in the studied populations of $A$. dioica, $\mathrm{B}$ - rosette diameter values; $\mathrm{N}$ - geobotanical releve (population) number; $\mathrm{D}$ - rosette diameter, $\mathrm{cm}$; $\mathrm{H}$ - generative shoot height, $\mathrm{cm}$; 1 - female individuals; 2 - male individuals
Tver regions, no significant differences between the sexes were found.

The number of capitula in the inflorescence varies from 1 to 20 (median=4). Most shoots carry 1 to 9 capitula; more than 10 capitula is a rare case (Fig. 4B). There are no direct correlation with the plant height $(\mathrm{r}=0.19$, $\mathrm{p}$-value $<2.2 \mathrm{e}-$ 16). In the entire sample, no significant difference between males and females were found; however, in some regions this regularity was recorded (Table 1).

The color of capitula in A. dioica is usually white (1 480 out of 1908 observations). Female flowers have pink color more often than male ones $(42.2 \%$ and $10.6 \%$ respectively), but statistically the difference was not reliable anywhere except the Tver region (Table 1). The populations from Tver region (unlike in other research points) included individuals of all colors: from white to dark pink.

The sample by rosette diameter has normal distribution (W $=0.9$, p-value $<2.2 \mathrm{e}-16)$ and low coefficient of variation $(4 \%)$. The smallest rosette diameters $(0.5-0.7 \mathrm{~cm})$ are recorded for individuals in alpine heaths, and the largest $(9 \mathrm{~cm})-$ in pine forests (Murmansk region). The average rosette diameter is $2.1 \pm 0.05 \mathrm{~cm}$.

Rosette diameters in male and female shoots have statistically significant difference for the entire sample (Table 1, Fig. 5). However, while analyzing this trait within specific groups of populations, we found significant difference only for those from Tver region. The trait values for both sexes demonstrate strong overlap (Fig. 2B) as well as in the case of plant height. On average, the female rosette diameter is $2 \pm 0.1 \mathrm{~cm}$, the male one is $2.5 \pm 0.04 \mathrm{~cm}$.

The most characteristic trait of the individuals studied is the pointed shape of leaf apex (№ 2 in Fig. 1). However, both male and female individuals with the same leaf shape coexist in the same population. In the entire sample, the intermediate leaf type with slightly pointed tip is represented most often. Male and female individuals differ significantly by this trait, but not in all regions (Table 1).

Males and females are not statistically different by hair density, though the difference is significant for $A$. dioica po-
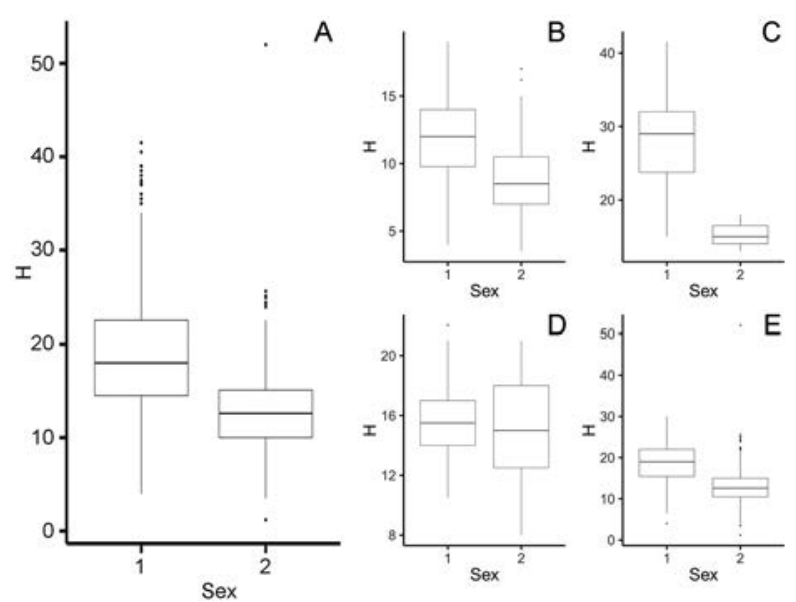

Figure 3 Boxplots of the dependence of $A$. dioica generative shoot height on sex for various regions. A - total sample, B - Murmansk region, $\mathrm{C}-$ Tver region, D - Moscow region, E - Bulgaria, 1 female individuals, $2-$ male individuals, $\mathrm{H}-$ height of shoot 
Table 1. Values of statistical tests for the difference between sexes in $A$. dioica. $\mathbf{N}$ - number of measurements, Type type of analysis: $\mathbf{t}$ - Two Sample t-test, $\mathbf{W}$ - Wilcoxon Rank Sum and Signed Rank Test, Value - value of statistics

\begin{tabular}{|c|c|c|c|c|c|}
\hline Trait & Region & $\mathbf{N}$ & Type & Value & P-value \\
\hline Height & $\begin{array}{l}\text { All } \\
\text { Murmansk } \\
\text { Tver } \\
\text { Moscow } \\
\text { Bulgaria }\end{array}$ & $\begin{array}{l}1907 \\
1202 \\
378 \\
141 \\
186 \\
\end{array}$ & $\begin{array}{l}\mathrm{t} \\
\mathrm{t} \\
\mathrm{t} \\
\mathrm{t} \\
\mathrm{t}\end{array}$ & $\begin{array}{l}26.81 \\
23.35 \\
1.83 \\
14.16 \\
6.82 \\
\end{array}$ & $\begin{array}{l}<0.05 \\
<0.05 \\
0.06 \\
<0.05 \\
<0.05\end{array}$ \\
\hline $\begin{array}{l}\text { Number } \\
\text { of cauline } \\
\text { leaves }\end{array}$ & $\begin{array}{l}\text { All } \\
\text { Murmansk } \\
\text { Tver } \\
\text { Moscow } \\
\text { Bulgaria }\end{array}$ & $\begin{array}{l}1905 \\
1143 \\
378 \\
141 \\
184 \\
\end{array}$ & $\begin{array}{l}\text { W } \\
\text { W } \\
\text { W } \\
\text { W } \\
\text { W }\end{array}$ & $\begin{array}{l}198765 \\
220440 \\
17954 \\
574 \\
5147 \\
\end{array}$ & $\begin{array}{l}<0.05 \\
<0.05 \\
0.88 \\
0.08 \\
0.01 \\
\end{array}$ \\
\hline $\begin{array}{l}\text { Number of } \\
\text { capitula }\end{array}$ & $\begin{array}{l}\text { All } \\
\text { Murmansk } \\
\text { Tver } \\
\text { Moscow } \\
\text { Bulgaria }\end{array}$ & $\begin{array}{l}1907 \\
1202 \\
378 \\
141 \\
186 \\
\end{array}$ & $\begin{array}{l}\text { W } \\
\text { W } \\
\text { W } \\
\text { W } \\
\text { W }\end{array}$ & $\begin{array}{l}13436 \\
162720 \\
15116 \\
465.5 \\
3153\end{array}$ & $\begin{array}{l}0.86 \\
0.02 \\
0.01 \\
0.53 \\
0.03\end{array}$ \\
\hline $\begin{array}{l}\text { Color of } \\
\text { capitula }\end{array}$ & $\begin{array}{l}\text { All } \\
\text { Murmansk } \\
\text { Tver } \\
\text { Moscow } \\
\text { Bulgaria }\end{array}$ & $\begin{array}{l}1907 \\
1202 \\
115 \\
6 \\
186 \\
\end{array}$ & $\begin{array}{l}\text { chi } \\
\text { chi } \\
\text { chi } \\
\text { chi } \\
\text { NA }\end{array}$ & $\begin{array}{l}1.35 \\
\mathrm{NaN} \\
28.975 \\
0 \\
\mathrm{NA}\end{array}$ & $\begin{array}{l}0.24 \\
\text { NA } \\
<0.05 \\
1 \\
\mathrm{NA} \\
\end{array}$ \\
\hline $\begin{array}{l}\text { Diameter } \\
\text { of rosette }\end{array}$ & $\begin{array}{l}\text { All } \\
\text { Murmansk } \\
\text { Tver } \\
\text { Moscow } \\
\text { Bulgaria }\end{array}$ & $\begin{array}{l}1335 \\
1114 \\
0 \\
35 \\
186 \\
\end{array}$ & $\begin{array}{l}\mathrm{t} \\
\mathrm{t} \\
\mathrm{t} \\
\mathrm{t} \\
\mathrm{t}\end{array}$ & $\begin{array}{l}6.01 \\
0.58 \\
\mathrm{NaN} \\
1.67 \\
0.003 \\
\end{array}$ & $\begin{array}{l}<0.05 \\
0.56 \\
\text { NA } \\
0.10 \\
0.99 \\
\end{array}$ \\
\hline $\begin{array}{l}\text { Shape of } \\
\text { leaf apex }\end{array}$ & $\begin{array}{l}\text { All } \\
\text { Murmansk } \\
\text { Tver } \\
\text { Moscow } \\
\text { Bulgaria }\end{array}$ & $\begin{array}{l}1335 \\
1114 \\
28 \\
6 \\
186 \\
\end{array}$ & $\begin{array}{l}\text { chi } \\
\text { chi } \\
\text { chi } \\
\text { chi } \\
\text { chi }\end{array}$ & $\begin{array}{l}13.72 \\
3.25 \\
106.23 \\
0 \\
4.003\end{array}$ & $\begin{array}{l}<0.05 \\
0.35 \\
<0.05 \\
1 \\
0.26 \\
\end{array}$ \\
\hline Hair density & $\begin{array}{l}\text { yAll } \\
\text { Murmansk } \\
\text { Tver } \\
\text { Moscow } \\
\text { Bulgaria }\end{array}$ & $\begin{array}{l}1335 \\
1114 \\
28 \\
6 \\
186\end{array}$ & $\begin{array}{l}\text { chi } \\
\text { chi } \\
\text { chi } \\
\text { chi } \\
\text { chi }\end{array}$ & $\begin{array}{l}64.19 \\
9.41 \\
131.94 \\
0 \\
0.70\end{array}$ & $\begin{array}{l}1.13 \\
0.02 \\
<0.05 \\
1 \\
0.70\end{array}$ \\
\hline
\end{tabular}

pulations in Murmansk and Tver regions (Table 1). In these populations, densely hairy leaves, silver-shaded in the sunlight prevail in male individuals, while female ones have sparsely hairy leaves without "mirror shine" effect. The populations also include individuals with all three trait values.

\section{DISCUSSION}

Our results demonstrate that $A$. dioica plants of different sexes differ significantly by some mean values of several morphological traits. However, no distinct qualitative (or quantitative) traits for identification of individuals' sex were found. All patterns and correlations were observed on statistical level, and using a trait as the attributive one requires measurements of numerous plants to determine the sex. Plant height demonstrated the highest statistical significance, although deviation from mean values was too high to provide accurate information for a single individual. However, the fact that female plants were averagely higher than males is of certain interest in the light of reproductive cost hypothesis. It states that female individuals tend to be lower than males because of reproduction costs, as it was demonstrated for Urtica dioica L. (Urticaceae) and Rumex acetosa L. (Polygonaceae) (Varga 2010). It is possible to suppose that higher female plants is a result of anemochory and therefore could be regarded as an adaptation to improve effectiveness of seed dispersal.

The significant difference between the sexes by a specific trait does not mean that male and female individuals will be significantly different by this trait within a certain geographical area. Therefore, all revealed patterns are purely statistical in nature and allow suggesting that the morphological manifestation of sex dimorphism in $A$. dioica is very low and depends, among other things, on environmental conditions.

Weak manifestation of sex dimorphism in $A$. dioica can be a result of either specific features of sex determination, or the fact that dioecy was acquired relatively late in evolutionary history of the species. Data on sex determination in A. dioica is still scarce. It is known that there are no sex chromosomes in its karyotype (Urbanska-Worytkiewicz 1967), and sex of an individual is likely to be determined by the ecological factors. Experiments of Varga \& Kytöviita (2011) demonstrated instability of sex determination in a clone: its sex can vary, changing between "male-female-male" or "female-male-female" during several years. Flower morpho-
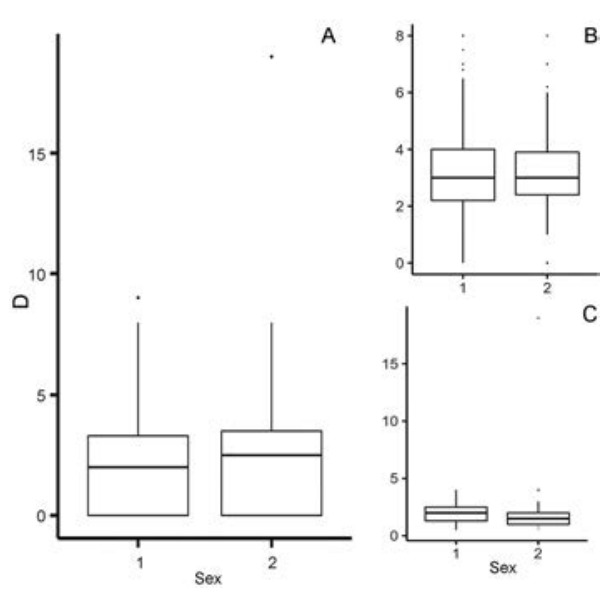

Figure 5 Boxplots of the dependence of $A$. dioica rosette diameter on sex of an individual. A - for the entire sample, B Murmansk region, $\mathrm{C}$ - Bulgaria. 1 - female, 2 - male individuals 
logy also suggests late emergence of dioecy in evolutionary history of $A$. dioica besides of morphologically female or intersex (functionally male) ones, numerous transitional forms were found for the species, including flowers with completely intersex features without any visible reduction (von Ubisch 1936, Dudova 2018).

Sex dimorphism is evident in morphology of $A$. dioica shoots only on the statistical level. Height of shoots, rosette diameter, and number of cauline leaves differ significantly between sexes. However, precise identification of individual shoots as male or female without assessing traits of capitula or flowers is difficult.

\section{ACKNOWLEDGEMENTS}

The reported study was funded by RFBR and Moscow city Government according to the research project № 19-3470018. Field collecting of samples was carried outinaccordance to Government order \# AAAA-A16-116021660039-1.

\section{LITERATURE CITED}

Barrett, S.C.H. 1992. Gender variation and the evolution of dioecy in Wurmbea dioica (Lilliaceae). Journal of Evolutionary Biology 5(3):423-444.

Barrett, S.C.H. \& J. Hough. 2012. Sexual dimorphism in flowering plants. Journal of Experimental Botany 64(1):67-82.

Borisova, A.G. 1959. Antennaria. In: Flora of USSR, vol. 25, (B.K. Shishkin, ed.), pp. 326-330. Izd-vo Akademii Nauk SSSR, Leningrad (in Russian). ББорисова А.Г. 1959. Antennaria // ФАора СССР. Т. 25. /поА реА. Б.К. Шишкина. АенинграА: изА-во АН СССР. С. 326-330].

Chmielewski, J.G., C.C. Chinnapa \& J.C. Semple 1990. The genus Antennaria (Asteraceae: Inuleae) in western North America: Morphometric analysis of Antennaria alborosea, A. corymbosa, A. marginata, A. microphylla, A. parvifolia, A. rosea, and $A$. umbrinella. Plant Systematics and Evolution 169(3):151-175.

Cipollini, M.L. \& D.F. Whigham 1994. Sexual dimorphism and cost of reproduction in the dioecious shrub Lindera benzoin (Lauraceae). American Journal of Botany 81(1):65-75.

Delph, L.F. 2003. Sexual dimorphism in gender plasticity and its consequences for breeding system evolution. Evolution \& Development 5(1):34-39.

Engelskjen, T. \& O. Skifte 1995. The vascularplants of Tromso, North Norway: revised distribution maps and altitude limits after benum. Tromsø. 227 pp.

Eppley, S.M., C.A. Mercer, C. Haaning \& C.B. Graves 2009. Sex-specific variation in the interaction between Distichlis spicata (Poaceae) and mycorrhizal fungi. American Journal of Botany 96(11):1967-1973.

Geber, M.A., E. Todd \& L.F. Delph 1999. Gender and sexual dimorphism in flowering plants. Heidelberg. 305 pp.

Gibson, D.J. 1994. Population structure and spatial pattern in the dioecious shrub Ceratiola ericoides. Journal of Vegetation Science 5(3):337-346.

Godin, V.N. 2007. Sex differentiation in plants. Terms and notions. Zhurnal Obshchei Biologii (Journal of General Biology) 68(2):98-108.

Gulenkova, M. \& S. Pyatunina 1996. Melandrium album. In: Biological flora of Moscow region, vol. 13 (V.N. Pavlov, ed.), pp. 88-96, Moscow University, Moscow (in Russian). [Гуленкова М., Пятунина С. 1996. Melandrium album // Биологи- ческая флора Московской области. Т. 13. / под реА. В.Н. Павлова. Москва: Московский университет. С. 88-96].

Hultine, K.R., S.E. Bush, A.G. West \& J.R. Ehleringer 2007. Population structure, physiology and ecohydrological impacts of dioecious riparian tree species of western North America. Oecologia 154(1):85-93.

Korpelainen, H. 1994. Sex ratios and resource allocation among sexually reproducing plants of Rubus chamaemorus. Annals of Botany 74(6):627-632.

Lloyd, D.C. \& C.J. Webb 1977. Secondary sex characters in seed plants. The Botanical Review 43(2):177-216.

Lloyd, D.G. \& A.J. Myall 1976. Sexual dimorphism in Cirsium arvense (L.) Scop. Annals of Botany 40(1):115-123.

Manoilov, E.O. 1924. Detection of the sex of dioecious species with the help of chemical reaction. Trudy po prikladnoy botanike $i$ selek.tsii 13(2): 503-505 (in Russian). [Маноймов Е.О. 1924. Определение пола у двудомных растений при помощи химической реакции // Труды по прикладной ботанике и селекции. Т. 13, № 2 . С. 503-505.

Meagher, T.R. 1984. Sexual dimorphism and ecological differentiation of male and female plants. Annals of Missouri Botanical Garden 71(1):254-264.

Meagner, T.R. \& D.E. Costich 1994. Sexual dimorphism in nuclear DNA content and floral morphology in populations of Silene latifolia (Caryophyllaceae). American Journal of Botany 81(9):1198-1204.

Miller, N.G. 1970. The genera of the Cannabaceae in the Southeastern United States. Journal of the Arnold Arboretum 51:185-203.

Pailler, T., L. Humeau \& J. Figier 1998. Reproductive trait variation in the functionally dioecious and morphologically heterostylous island endemic Chassalia corallioides (Rubiaceae). Biological Journal of Linnean Society 64(3):297-313.

Parasnis, A.S., W. Ramakrishna, K.V. Chowdari, V.S. Gupta \& P.K. Ranjekar 1999. Microsatellite (GATA)n reveals sex-specific differences in Papaya. Theoretical and Applied Genetics 99(6):1047-1052.

R Core Team 2018. Rstudio V.1.1.456. https://www.rstudio. com/. Last accessed 25 January 2019.

Rottenberg, A. 1998. Sex ratio and gender stability in the dioecious plants of Israel. Botanical Journal of Linnean Society 128(2):137-148.

Shibu, M.P., K.V. Ravishankar, L. Anand, K.N. Ganeshaiah \& R.U. Shaanker 2000. Identification of sex-specific DNA markers in the dioecious tree, nutmeg (Myristica fragrans Houtt.). Plant Genetic Resources Newsletter 121:59-61.

Stehlik, I. \& F.R. Blattner 2004. Sex-specific SCAR markers in the dioecious plant Rumex nivalis (Polygonaceae) and implications for the evolution of sex chromosomes. Theoretical and Applied Genetics 108(2):238-242.

Thomas, S.C. \& J.V. LaFrankie 1993. Sex, size and interyear variation in flowering among dioecious trees of the Malayan rain forest. Ecology 74(5):1529-1537.

Urbanska-Worytkiewicz, K. 1967. Embryological investigations in Antennaria. Micro- and macrosporogenesis in natural hybrids between $A$. carpatica (Wahlenb.) Bluff. et Fingerh. and $A$. dioica (L.) Garetn. Acta Biologica Cracoviensia 14:21-36.

Varga, S. \& M.-M. Kytöviita 2008. Sex-specific responses to mycorrhiza in a dioecious species. American Journal of Botany 95(10):1225-1232. 
Varga, S.\& M.-M.Kytöviita 2010. Interrelationships between mycorrhizal symbiosis, soil $\mathrm{pH}$ and plant sex modify the performance of Antennaria dioica. Acta Oecologica 36(3): 291-298.

Varga, S.\& M.-M. Kytöviita 2011. Sex ratio and spatial distribution of male and female Antennaria dioica (Asteraceae) plants. Acta Oecologica 37(5):433-440.

von Ubisch, G., 1936. Genetic studies on the nature of hermaphroditic plants in Antennaria dioica (L) Gaertn. Genetics 21(3):282-294.

Webb, D.J.L. \& L.F. Delph 1999. Gender dimorphism in indigenous New Zealand seed plants. New Zealand Journal of Botany 37(1):119-130.

Wickham H., Chang W., Henry L. 2018. Gplot2: Create Elegant Data Visualisations Using the Grammar of Graphics. R package version 3.1.0. https://CRAN.R-project.org/ package $=$ ggplot 2 . Last accessed 25 January 2019.

Wickham H., François R., Henry L. et al. 2018. Dplyr: A Grammar of Data Manipulation. R package version 0.7.8. https://CRAN.R-project.org/package=dplyr. Last accessed 25 January 2019.

Zluvova, J., M. Nicolas, A. Berger, I. Negrutiu \& F. Moneager 2006. Premature arrest of the male flower meristem precedes sexual dimorphism in the dioecious plant Silene latifolia. Proceedings of the National Academy of Sciences of the United States of America 103:18854-18859. 